\title{
Strip-till technology - a method for uniformity in the emergence and plant growth of winter rapeseed (Brassica napus L.) in different environmental conditions of Northern Poland
}

\author{
Iwona Jaskulska, Lech Gałęzewski, Mariusz Piekarczyk, Dariusz Jaskulski \\ Department of Plant Production and Experimentation, University of Science and Technology in Bydgoszcz, \\ Bydgoszcz, Poland
}

\begin{abstract}
The emergence of plants is especially important for the winter crops that are grown in the challenging environmental conditions of many countries in Central and Eastern Europe. The emergence and initial growth of winter rapeseed were compared in field trials in a randomized block design with three replicates for plants sown in conventional tillage systems (CT) and strip-till (ST), which had different weather conditions and on soil with a non-uniform texture over a period of two years. Sowing in the CT was carried out using Horsch Pronto 4DC (Germany) at a row distance of 0.29 $\mathrm{m}$. The ST operations were performed using a Pro-Til 4T drill manufactured by Mzuri Limited (Great Britain) - row spacing of $0.36 \mathrm{~m}$. In favourable rainfall and thermal conditions, the density of winter rapeseed plants two weeks after sowing was found to be higher if it was sown after the CT than in the ST system. In the year that had a serious shortage of rainfall during the sowing period, a considerably higher density of plants was achieved using the ST system. The uniformity of plant growth using the ST technology in soil with a varied texture, especially in a year with an unfavourable distribution of rainfall, was proven by less variability in the number of leaves in the rosette, in the dry mass of the leaf rosette and in the root neck thickness of the winter
\end{abstract}

Correspondence: Dariusz Jaskulski, Department of Plant Production and Experimentation, University of Science and Technology in Bydgoszcz, 20E Kordeckiego Street, 85-225 Bydgoszcz, Poland.

E-mail: darekjas@utp.edu.pl

Key words: Environmental conditions; plant uniformity; tillage systems.

Acknowledgements: we thank Agro-Land Marek Różniak at Śmielin for the opportunity to perform a field experiment.

Received for publication: 5 April 2017.

Revision received: 27 July 2017.

Accepted for publication: 1 August 2017.

(C) Copyright I. Jaskulska et al., 2018

Licensee PAGEPress, Italy

Italian Journal of Agronomy 2018; 13:981

doi:10.4081/ija.2018.981

This article is distributed under the terms of the Creative Commons Attribution Noncommercial License (by-nc 4.0) which permits any noncommercial use, distribution, and reproduction in any medium, provided the original author(s) and source are credited. rapeseed than in the $\mathrm{CT}$ system. The ST system can create good conditions for the initial development and preparation of rapeseed plants for wintering.

\section{Introduction}

Rapeseed (Brassica napus L.) is one of the most important oilseed crops in the world (Dyer et al., 2008; Hu et al., 2017). Its winter form is mostly cultivated in Europe. The winter rapeseed acreage in Poland is about 0.7-0.8 $\mathrm{m}$ ha annually (FAO, 2016). Cultivation success and seed yield considerably depend on the plant development in autumn and overwintering (Balodis and Gaile, 2015). The conditions for the crops to reach the optimal development stage and good overwintering are their evenly distributed emergence and a field that is composed of plants that are even in terms of size and condition (Velicka et al., 2005; Velicka et al., 2012). The emergence rate and speed depend on e.g. soil properties, especially the seedbed (Håkansson et al., 2011). This is of special importance for plants with small seeds, including rapeseed (Håkansson et al., 2013; Alizadeh and Allameh, 2015). The reasons behind uneven emergence and initial growth of seedlings within a plantation are varied soil conditions in the field. Even in small-sized fields, the soil can be strongly diversified in terms of its origin, classification and properties (Brevik et al., 2003; Godwin and Miller, 2003). Soil properties, especially the physical ones, such as moisture, temperature, bulk density, soil penetration, are all shaped by the tillage system (Strudley et al., 2008; Alvarez and Steinbach, 2009).

Tillage should facilitate a shallow precise sowing and ensure evenly-distributed germination conditions for all of the seeds. According to many research reports, the best tillage method for plants such as rapeseed is traditional plow tillage (Vanda et al., 2009). Unfortunately, this is very energy-consuming (Kusek et al., 2016). Frequently, it also has a deteriorating effect on the properties of soil and other elements of the environment (Kertesz and Madarasz, 2014). Inversion of soil and deep soil loosening strongly aerate soil and cause water loss (Guan et al., 2015). For that reason, today reduced tillage and direct sowing are frequently applied. In those tillage systems, much post-harvest residues or mulch remains on the soil surface, thus protecting it against erosion. Conservation tillage enhances water management and organic matter, requires low inputs and produces low emissions (Derpsch et al., 2010; Busari et al., 2015; Choudhary, 2015). Plant residues, however, can make sowing difficult and limit germination, emergence and initial plant growth (Wuest et al., 2000). Zero tillage often results in a decreased rapeseed yield and economic effectiveness of its cultivation (Khakbazan and Hamilton, 2012). 
In contemporary agriculture, strip-till, which combines the advantages of conventional tillage, zero tillage and direct sowing, is often used. Hybrid machines in strip-till technology are especially valuable because in a single go they till the soil deep, apply mineral fertilisers and sow seeds (Morris et al., 2010). Compared with the traditional tillage, this system has shows a very favourable effect on the agricultural soil properties, economic and organisational plant growing effectiveness and on the environment (Licht and Al-Kaisi, 2005; Jabro et al., 2014). Al-Kaisi et al. (2014), when comparing the effect of five tillage systems, e.g. strip-till and plow tillage, on the soil structure found that the effect of zero tillage and strip-till were most beneficial for the stability of micro- and macroaggregates. A significant positive correlation was also recorded between the content of organic carbon in soil and the waterresistance of micro- and macro-aggregates. As reported by Fernández et al. (2015), after only a few years of applying strip-till, the content of organic matter in soil increased. Strickland et al. (2015) demonstrated that after five years of plant cultivation following the principles of conservation agriculture with a winter soil coverage with rye and pea biomass and strip-till, the content of organic carbon and total nitrogen in soil increased. Most, about 70$80 \%$, of the organic carbon got deposited in the surface layer. For the emergence and further plant growth, a favorable effect on soil moisture and temperature, especially in the seedbed, is of similar importance (Al-Kaisi and Yin, 2005). According to Overstreet (2009), strip-till is also favourable due to the lower production costs resulting from decreased fuel consumption as well as a shortening of work time. For that reason, strip-till technology is being more and more frequently applied in plant cultivation, especially those sown in wide-spaced rows (Jackson et al., 2011), mostly corn (Trevini et al., 2013) or sugar beets (Morris et al., 2007). However, there are a few results of research into growing plants with a narrow row spacing, e.g. cereal crops (Hossain et al., 2014) and rapeseed (Schwabe et al., 2016). There are no such results for Poland.

A hypothetical assumption has been made that in spite of the beneficial effects of strip-till on soil properties, which is especially important for plant growth and yield, winter rapeseed that is grown in compliance with that technology will have an evenly-distributed emergence and at the end of the autumn plant vegetation period, the plants will be even in terms of size, which determines the final cultivation success. Such an assumption was justified when considering the earlier observations of the performance of a hybrid machine that permits three agrotechnical practices to be performed in one go - soil belt tillage, mineral fertiliser application and rapeseed sowing in $36 \mathrm{~cm}$-spaced rows, which is to the result of the machine design. In traditional winter rapeseed tillage technology in Poland, the row-spacing is smaller and, depending on the seeders that are used, it is $15-30 \mathrm{~cm}$. The scientific literature shows, however, that the effect of row-spacing on rapeseed growth and yield depends on genetic factors, the environmental conditions and agrotechnical practices and that the largest yields can be produced for even $60 \mathrm{~cm}$ row-spacing (Waseem et al., 2014; Kuai et al., 2015).

\section{Materials and methods}

\section{Field trial design}

In 2014-2015 and 2015-2016, a one-factor field experiment in a randomised block design was carried out on Cambisols at a farm in the village of Śmielin, North Poland (530. $\left.09^{\prime} 04^{\prime \prime} \mathrm{N} ; 17^{\circ} 29^{\prime} 11^{\prime \prime} \mathrm{E}\right)$, which collaborates with the Department of Agriculture and Biotechnology of the Bydgoszcz University of Science and Technology. The subject of research was the winter rapeseed cv. 'Apanaci', which was cultivated in a region with low rainfall - about $500 \mathrm{~mm}$ per year. Two tillage and sowing systems were compared - conventional (CT) and strip-till (ST) on large plots $(24 \times 300 \mathrm{~m})$ in three replicates. In the $\mathrm{CT}$, after the forecrop harvest (spring barley), the following were used: a stubble field cultivator, a plough, a fertiliser spreader, a pre-sowing cultivation unit and a seed drill. A Horsch Pronto 4DC (Germany) seed drill sowed seeds to a depth of $2.5-3.0 \mathrm{~cm}$ at a row spacing of $0.29 \mathrm{~m}$. In the strip-till system, a onepass tillage, fertiliser application and rapeseed sowing operations were performed using a Pro-Til 4T hybrid machine manufactured by Mzuri Limited, Great Britain. The row spacing was $0.36 \mathrm{~m}$ and the sowing depth was also $2.5-3.0 \mathrm{~cm}$. Prior to sowing, $18 \mathrm{~kg} \mathrm{~N} \mathrm{ha}^{-1}$ and $20 \mathrm{~kg} \mathrm{P} \mathrm{ha}^{-1}$ (ammonium phosphate) and $67 \mathrm{~kg} \mathrm{~K} \mathrm{ha}^{-1}$ (potassium chloride) were applied. The winter rapeseed was sown at a density of 45 seeds $\mathrm{m}^{-2}$ on 9 August 2014 and 12 August 2015 respectively.

\section{Soil samples and properties}

Prior to establishing the trials, soil samples were collected from all of the replicates from the $0-20 \mathrm{~cm}$ layer every $20 \mathrm{~m}$. The soil texture was determined for each sample (Table 1). The soil within the trial field was diversified. Its texture was loam, sandy loam and silt loam. Knowing the impact of the applied tillage and sowing methods on the uniformity of the emergence and initial growth of plants in different environmental conditions of the selection of the research site was justified.

\section{Plant samples}

In both study years, plant density was measured three times, 2 and 4 weeks after sowing and at the end of the autumnal growing season. Plant density was assessed for an area of $1 \mathrm{~m}^{2}$ every $20 \mathrm{~m}$ at 15 spots for each replicate. At the end of October, random samples of 20 plants were taken from the exact same spots in order to examine the leaf rosette and root neck. The examination included the number of leaves in the rosette of the winter rapeseed, the dry mass of leaves and the thickness of the root neck.

\section{Statistical analyses}

Data were subjected to a statistical assessment. A one-factor ANOVA analysis of variance was carried out. The significance of the differences between the means was estimated post-hoc using the

Table 1. The percentages of sand, silt, and clay particles in experimental field soil and their variation.

\begin{tabular}{lcccc}
\hline & & $\begin{array}{c}\text { Relative proportion (\%) in soil } \\
\text { Marticle sive }\end{array}$ & Mean & $\begin{array}{c}\text { Coefficient of variation } \\
\text { (\%) }\end{array}$ \\
\hline $2-0.05 \mathrm{~mm}$ & 32.2 & Maximum & 41.1 & 13.1 \\
$0.05-0.002 \mathrm{~mm}$ & 42.2 & 50.2 & 52.0 & 9.7 \\
\hline$<0.002 \mathrm{~mm}$ & 5.7 & 59.9 & 7.0 & 8.4 \\
\hline
\end{tabular}


Tukey's test. The variability of plant densities and biometric properties of winter rapeseed plants within the trial field was evaluated for the respective tillage and sowing systems in both years. The basic statistics that were determined for this purpose were the minimum ( $\min )$, maximum ( $\max )$ and mean values; standard deviation (SD) and standard error (SE). Statistica 12.5 (StatSoft Inc., Tulsa, USA) statistical software was used for the data analysis.

\section{Results}

The two years differed in terms of weather conditions during the periods of sowing, emergence and initial growth of winter rapeseed. In 2014, in the decade (10-day period) immediately preceding the sowing and following the sowing, the precipitation was uniform and at a level that was close to the long-term mean (LTM). At the same time, the air temperature in the second and third decade of August was lower than the LTM. August 2015 was, on the other hand, very hot and dry. The sum of rainfall in the two decades following the sowing of the winter rapeseed did not exceed $10 \mathrm{~mm}$, while the air temperature in every decade was higher (Figures 1 and 2).

In the favorable precipitation and thermal conditions in 2014, the initial density of the winter rapeseed plants was higher than in 2015. Two weeks after sowing, the plant density after the CT was considerably greater than in the ST system, but it did not increase any further in the following weeks of the growing period (Figure 3). In 2015, which had a serious shortage of rainfall in August, a significantly higher plant density was observed in the CT system in the first assessment period. Only after the rains at the beginning of September did the plant densities equalise in both tillage systems four weeks after sowing. At the end of the autumnal growing season, the plant densities were similar and equaled 32.6-35.6 plants $\mathrm{m}^{-2}$ in both years and in the CT and ST systems.

The beneficial influence of the ST system on the speed and uniformity of emergence in the case of the water shortage in the soil occurred especially in 2015 . This was proven by a lower SD and $\mathrm{SE}$ and fewer differences between the max and min values than for the CT system (Table 2). The number of leaves in a rosette, the dry mass of the aboveground part of the plants and the thickness of the root neck for the ST technology in both years were higher and more uniform than for the CT. There was a better uniformity of the plants from various places in the differentiated experimental field in the ST system than in the CT, especially in the unfavorable water and thermal conditions of 2015, which caused the lower values of the SD and SE.

\section{Discussion}

The uniform emergence of plants is the first and foremost condition for appropriate canopy formation and good yield in crops. The extent and rate of emergence depends on the quality of the sowing material. Ghassemi-Golezani et al. (2010) found that the emergence of rapeseed from seeds with a lower vitality is poorer and lasts longer. No less important are the habitat factors, especially the soil properties and weather conditions, as well as the techniques of soil preparation and sowing. In field production, these factors usually exert a combined influence. Kutcher and Malhi (2010), when conducting research into the impact of forecrop plant residue and tillage with various properties on the yield of plants,

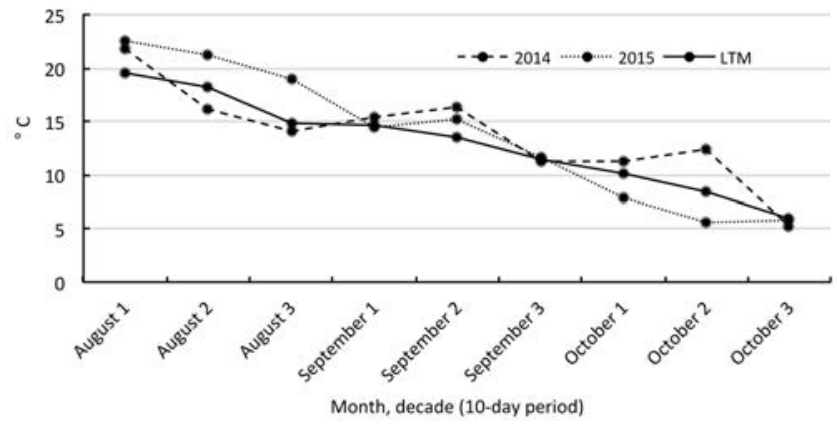

Figure 1. 10-day period mean temperature trend during the sowing and initial rapeseed growth in 2014, 2015, and long-term period (LTM) at the experimental site.

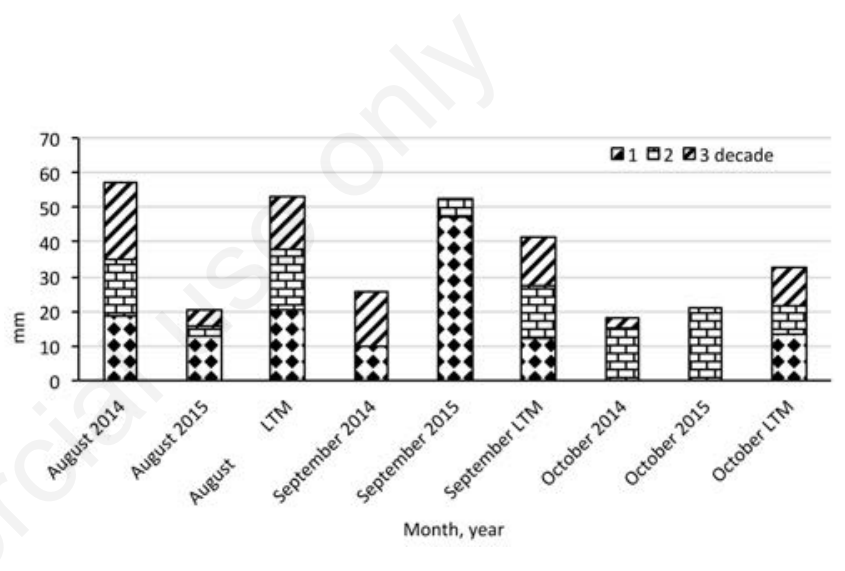

Figure 2. 10-day period (decade) and monthly sum of rainfall during the sowing and initial rapeseed growth in 2014, 2015, and long-term period (LTM) at the experimental site.

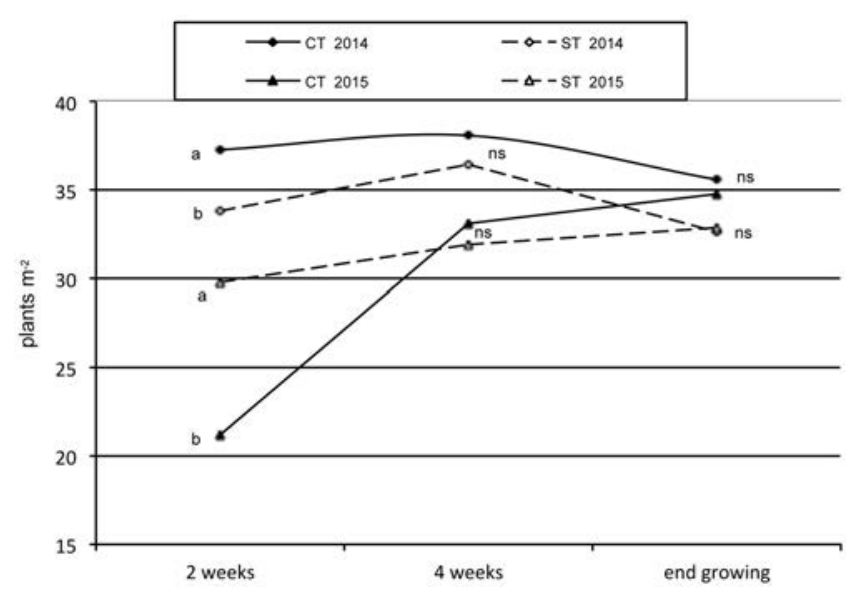

Figure 3. Winter rapeseed plant density (plants $\mathbf{~ m}^{-2}$ ) in two years depending on tillage and sowing system (CT, conventional; ST, strip-till) 2, 4 weeks after sowing and at the end of the autumnal growing season. a, b, significant differences; ns, insignificant differences. 
determined, among others, that the habitat and tillage system interacted in their influence on rapeseed emergence. A larger emergence after zero-tillage than in the conventional system occurred in one of two locations, in four out of five years of the research. The authors attributed this to a higher soil moisture content and a lack of destruction of the top soil layer in the zero-tillage system. The results of model tests (Rinaldi et al., 2005) indicate that the germination and emergence of plants is greatly influenced by the soil moisture content and its texture. In our study, when the quantity and distribution of rainfall in the winter rapeseed sowing period of 2014 was favourable for plant emergence, over $90 \%$ of the maximum number of plants that were later determined to be growing on individual establishments had emerged after only two weeks, regardless of the tillage system that was used. On the other hand, in 2015, when rainfall was scarce and the soil that was tilled in the CT was severely overdried, the plant density two weeks after sowing failed to reach as little as $50 \%$ of the sowing density. This was probably due to the lack tillage after the forecrop harvest and the straw that was used as mulch on surface of the soil and then the rapeseed drilling in the ST system, which allowed the soil to retain enough moisture to permit the seeds to germinate. Thus, the emergence of the winter rapeseed was good and more uniform within the trial field with varied soil conditions than after the CT. Earlier research by other authors indicated that eliminating ploughing may increase the degree of rapeseed emergence (Taghinezhad et al., 2012). Strip-till also has a beneficial influence on the emergence of plants due to the top soil layer being protected against water evaporation and temperature increases in the cultivated strip. Soil conditions, emergence and initial growth of plants in the strip-till system, however, depends on the depth and width of the strip under cultivation and the weather in the respective period (Schillinger, 2005; Celik et al., 2013).

In 2015, a rainfall shortage at the time of rapeseed sowing and initial growth caused a considerable, generally greater than in 2014, differentiation of emergence and, subsequently, seedling size within the trial field with a varied soil texture. The uniformity of plant density, the number of leaves in a rosette, the dry mass of leaves and the root neck diameter after the ST was, nevertheless, much higher than after the CT. This was proven by the lower values of the standard deviation of the plant properties, which were investigated in the experiment. Coupled with the results of other research, this is to be attributed to the beneficial influence of conservation tillage on those soil properties that play a role in plant emergence and growth. The results of numerous research projects (Fuentes et al., 2009; Brunel et al., 2013) indicate that minimumtillage systems retain more water in the soil than conventional systems. This is made possible by the plant residue that is left on the surface, less water runoff, better water infiltration, lower evaporation and a higher organic matter content. Wang et al. (2007) determined that the beneficial influence of conservation tillage on soil moisture and plant yield was especially visible in the dry years. Soil moisture is the key property that impacts plant emergence and growth. In the research conducted by Hosseini et al. (2009), a decrease in the soil moisture content from $75 \%$ to $25 \%$ field capacity led to the shrinking of chickpea emergence from $86.4 \%$ to $56.5 \%$ and extended the emergence period from 6.2 to 13.9 days. The plants were $15.3 \mathrm{~cm}$ shorter, had a $79.3 \mathrm{~cm}$ lower leaf area and a $0.62 \mathrm{~g}$ lower mass of the aboveground part. Our and other authors' research indicates that for the emergence to be fast and seedling growth to be uniform, the tillage system used ought to shape other soil properties as well, especially the seedbed. According to Nasr and Selles (1995), the extent and rate of emergence depends on soil density, the size of the aggregates and the interaction between the two. A high soil density and aggregate size are the limiting factors for plant emergence. High soil density is found to have a negative influence on emergence, mainly when the seedbed contains small aggregates. Önemli (2004) demonstrated that plant emergence improves together with an increase of the organic matter content in the soil. Its role is particularly important in years with little rainfall and high air temperatures.

\section{Conclusions}

In the year in which the period preceding the sowing of the winter rapeseed and immediately afterwards saw a high shortfall of rain, it was the ST system that promoted the fast and uniform emergence of rapeseed. In such weather conditions and in a field with a spatially varied soil texture, the plants grown using the ST system were more uniform prior to wintering than after the CT. The higher uniformity of the plants grown using the ST technology in a field with a varied soil texture than in the CT system, especially in

Table 2. Mean value of characteristics of winter rapeseed plant, their range and variability.

\begin{tabular}{|c|c|c|c|c|c|c|c|c|c|c|}
\hline \multirow[t]{2}{*}{ Tillage method } & \multicolumn{5}{|c|}{2014} & \multicolumn{5}{|c|}{2015} \\
\hline & Mean & Min & Max & SD & SE & Mean & Min & Max & SD & SE \\
\hline \multicolumn{11}{|c|}{ Plant density (pcs. $\mathrm{m}^{-2}$ ) } \\
\hline $\mathrm{CT}$ & 37.2 & 30.0 & 44.0 & 4.07 & 0.74 & 21.2 & 8.0 & 33.0 & 7.49 & 1.36 \\
\hline ST & 33.8 & 27.0 & 42.0 & 3.97 & 0.73 & 29.8 & 21.0 & 41.0 & 5.67 & 1.03 \\
\hline \multicolumn{11}{|c|}{ Number of leaves in rosette (pcs.) } \\
\hline CT & 11.2 & 9.7 & 12.5 & 0.70 & 0.13 & 9.0 & 6.3 & 11.0 & 1.23 & 0.22 \\
\hline ST & 11.9 & 10.7 & 13.0 & 0.55 & 0.10 & 10.6 & 9.0 & 12.0 & 0.87 & 0.16 \\
\hline \multicolumn{11}{|c|}{ Dry mass of leaf rosette (g d.m.) } \\
\hline $\mathrm{CT}$ & 5.1 & 4.7 & 5.5 & 0.23 & 0.04 & 3.8 & 2.8 & 4.8 & 0.60 & 0.11 \\
\hline ST & 5.6 & 5.1 & 6.0 & 0.19 & 0.04 & 4.8 & 4.0 & 5.2 & 0.32 & 0.06 \\
\hline \multicolumn{11}{|c|}{ Root neck thickness (mm) } \\
\hline $\mathrm{CT}$ & 14.2 & 12.1 & 15.6 & 0.90 & 0.17 & 10.3 & 8.7 & 12.4 & 1.10 & 0.20 \\
\hline ST & 15.7 & 13.7 & 17.3 & 0.82 & 0.15 & 13.9 & 12.5 & 14.8 & 0.66 & 0.12 \\
\hline
\end{tabular}

Min, minimum values; Max, maximum values; SD, standard deviation; SE, standard error; CT, conventional; ST, strip-till. 
a year with an unfavorable distribution of rainfall, was proven by lower factors of variability in the number of leaves in a rosette, the dry mass of the leaf rosette and root neck thickness. The probability of such plants overwintering and then producing high yields is greater than with strongly diversified plants in terms of their morphology and physiology. The ST may very well be a good system for the tillage and sowing of rapeseed in unfavorable field habitats that have rainfall shortages and different soil textures.

\section{References}

Alizadeh MR, Allameh A, 2015. Soil properties and crop yield under different tillage methods for rapeseed cultivation in paddy fields. J. Agric. Sci. 60:11-22.

Al-Kaisi MM, Douelle A, Kwaw-Mensah D, 2014. Soil microaggregate and macroaggregate decay over time and soil carbon change as influenced by different tillage systems. J. Soil Water Conserv. 69:574-80.

Al-Kaisi MM, Yin X, 2005. Tillage and crop residue effects on soil carbon and carbon dioxide emission in corn-soybean rotations. J. Environ. Qual. 34:437-45.

Alvarez R, Steinbach HS, 2009. A review of the effects of tillage systems on some soil physical properties, water content, nitrate availability and crops yield in the Argentine Pampas. Soil Till. Res. 104:1-15.

Balodis O, Gaile Z, 2015. Changes of winter oilseed rape plant survival during vegetation. Proc. Latv. Univ. Agr. 33,1:35-45.

Brevik EC, Fenton TE, Jaynes DB, 2003. Evaluation of the accuracy of a central Iowa soil survey and implications for precision soil management. Prec. Agr. 4:331-42.

Brunel N, Seguel O, Acevedo E, 2013. Conservation tillage and water availability for wheat in the dryland of central Chile. J. Soil Sci. Plant Nutr. 13:622-37.

Busari MA, Kukal SS, Kaur A, Bhatt R, Dulazi AA, 2015. Conservation tillage impacts on soil, crop and the environment. Int. Soil Water Conserv. Res. 3:119-29.

Celik A, Altikat S, Way TR, 2013. Strip tillage width effects on sunflower seed emergence and yield. Soil Till. Res. 131:20-7.

Choudhary VK, 2015. Tillage and mulch effects on productivity and water use of pea and soil carbon stocks. Arch. Agron. Soil Sci. 61:1013-27.

Derpsch R, Friedrich T, Kassam A, Hongwen L, 2010. Current status of adoption of no-till farming in the world and some of its main benefits. Int. J. Agric. Biol. Eng. 3:1-25.

Dyer J, Stymne S, Green A, Carlsson A, 2008. High value oils from plants. Plant J. 54:640-54.

FAO, 2016. FAOSTAT - Crops. Available from: http://www.fao.org/faostat/en/\#data/QC

Fernández FG, Sorensenb BA, Villamil MB, 2015. A comparison of soil proper-ties after five years of no-till and strip-till. Agron. J. 107:1339-46.

Fuentes M, Govaerts B, De León F, Hidalgo C, Dendooven L, Sayre KD, Etchevers J, 2009. Fourteen years of applying zero and conventional tillage, crop rotation and residue management systems and its effect on physical and chemical soil quality. Eur. J. Agron. 30:228-37.

Ghassemi-Golezani K, Khomari S, Dalil B, HosseinzadehMahootchy A, Chadordooz-Jeddi A, 2010. Effects of seed aging on field performance of winter oilseed rape. J. Food Agric. Environ. 8:75-178.

Godwin RJ, Miller PCH, 2003. A review of the technologies for mapping within-field variability. Biosyst. Eng. 84:393-407.

Guan D, Zhang Y, Mahdi M, Kaisi A, Wang Q, Zhang M, Li Z, 2015. Tillage practices effect on root distribution and water use efficiency of winter wheat under rain-fed condition in the North China Plain. Soil Till. Res. 146:286-95.

Håkansson I, Arvidsson J, Etana A, Rydberg T, Keller T, 2013. Effects of seedbed properties on crop emergence. 6. Requirements of crops with small seeds. Acta Agric. Scand. B 63:554-63.

Håkansson I, Arvidsson J, Keller T, Rydberg T, 2011. Effects of seedbed properties on crop emergence: 1 . Temporal effects of temperature and sowing depth in seedbeds with favourable properties. Acta Agric. Scand. B 61:458-68.

Hossain MI, Gathala MK, Tiwari TP, Hossain MS, 2014. Strip tillage seeding technique: A better option for utilizing residual soil moisture in rainfed moisture stress environments of NorthWest Bangladesh. Int. J. Recent Dev. Eng. Technol. 2:132-6.

Hosseini NM, Siddique KHM, Palta JA, Berger J, 2009. Effect of soil moisture content on seedling emergence and early growth of some chickpea (Cicer arietinum L.) genotypes. J. Agric. Sci. Technol. 11:401-11.

Hu Q, Hua W, Yin Y, Zhang X, Liu L, Shi J, Zhao Y, Qin L, Chen C, Wang H, 2017. Rapeseed research and production in China. Crop J. 5:127-35.

Jabro JD, Stevens WB, Iverson WM, Evans RG, Allen BL, 2014. Crop water productivity of sugarbeet as affected by tillage. Agron. J. 106:2280-6.

Jackson JL, Beasley JP, Tubbs RS, Lee RD, Grey TL, 2011. Fallbedding for reduced digging losses and improved yield in strip-till peanut. Peanut Sci. 38:31-40.

Kertesz A, Madarasz B, 2014. Conservation agriculture in Europe. Int. Soil Water Conserv. Res. 2:91-96.

Khakbazan M, Hamilton C, 2012. Economic evaluation of tillage management practices at the watershed scale in southern Manitoba. Soil Till. Res. 118:40-51.

Kuai J, Sun Y, Zuo Q, Huang H, Liao Q, Wu C, Lu J, Wu J, Zhou $\mathrm{G}, 2015$. The yield of mechanically harvested rapeseed (Brassica napus L.) can be increased by optimum plant density and row spacing. Sci. Rep. 5:231-50.

Kusek G, Ozturk HH, Akdemir S, 2016. An assessment of energy use of different cultivation methods for sustainable rapeseed production. J. Clean. Prod. 112:2772-783.

Kutcher HR, Malhi SS, 2010. Residue burning and tillage effects on diseases and yield of barley (Hordeum vulgare) and canola (Brassica napus). Soil Till. Res. 109:153-60.

Licht M, Al-Kaisi M, 2005. Strip-tillage effect on seedbed soil temperature and other soil physical properties. Soil Till. Res. 80:233-49.

Morris NL, Miller PCH, Orson JH, Froud-Williams RJ, 2007. Soil disturbed using a strip tillage implement on a range of soil types and the effects on sugar beet establishment. Soil Use Manage. 23:428-36.

Morris NL, Miller PCH, Orson JH, Froud-Williams RJ, 2010. The adoption of non-inversion tillage systems in the United Kingdom and the agronomic impact on soil, crops and the environment-a review. Soil Till. Res. 108:1-15.

Nasr HM, Selles F, 1995. Seedling emergence as influenced by aggregate size, bulk density, and penetration resistance of the seedbed. Soil Till. Res. 34:61-76.

Overstreet LF, 2009. Strip tillage for sugarbeet production. Int. Sugar J. 111:292-304.

Önemli F, 2004. The effects of soil organic matter on seedling emergence in sunflower (Helianthus annuus L.). Plant Soil 
Environ. 50:494-9.

Rinaldi M, Di Paolo E, Richter GM, Payne RW, 2005. Modelling the effect of soil moisture on germination and emergence of wheat and sugar beet with the minimum number of parameters. Ann. Appl. Biol. 147:69-80.

Schillinger WF, 2005. Tillage method and sowing rate relations for dryland spring wheat, barley, and oat. Crop Sci. 45:2636-43.

Schwabe S, Gruber S, Weber EA, Claupein W, 2016. Vorzüglichkeit des Clearfield - Systems bei Raps unter verschiedenen Bewirtschaftungsintensitäten. 27 ${ }^{\text {th }}$ German Conference on Weed Biology and Weed Control, February 23-25, 2016. Julius Kühn Archiv. 452:206-9.

Strickland TC, Scully BT, Hubbard RK, Sullivan DG, Abdo Z, Savabi MR, Lee RD, Olson DM, Hawkins GL, 2015. Effect of conservation practices on soil carbon and nitrogen accretion and crop yield in a corn production system in the southeastern coastal plain, United States. J. Soil Water Conserv. 70:170-81.

Strudley MW, Green TR, Ascough II JC, 2008. Tillage effects on soil hydraulic properties in space and time: state of the science. Soil Till. Res. 99:4-48.

Taghinezhad J, Mohseni-Niari S, Javadi A, 2012. Effect of different methods of seedbed preparation on irrigated canola yield after corn in North West Iran. Afr. J. Agric. Res. 7:5558-63.

Trevini M, Benincasa P, Guiducci M, 2013. Strip tillage effect on seedbed tilth and maize production in Northern Italy as casestudy for the Southern Europe environment. Eur. J. Agron. 48:50-6.

Vanda SF, Aynehband A, Naraki F, 2009. Effects of tillage method, seed rate and microelement spraying time on grain yield and yield components of rapeseed (Brassica napus) in warm dryland condition. Food Agric. Environ. 7:627-33.

Velicka R, Pupaliene R, Butkeviciene LM, Kriauciuniene Z, 2012. Peculiarities of overwintering of hybrid and conventional cultivars of winter rapeseed depending on the sowing date. Acta Sci. Pol. Agricult. 11:53-66.

Velicka R, Rimkeviciene M, Novickiene L, Anisimoviene N, Brazauskiene I, 2005. Improvement of oil rape hardening and frost tolerance. Russ. J. Plant Physiol. 52:473-80.

Wang X, Cai D, Hoogmoed W, Oenema O, Perdok U, 2007. Developments in conservation tillage in rainfed regions of North China. Soil Till. Res. 93:239-50.

Waseem M, Baloch D, Khan I, 2014. Influence of various row spacing on the yield and yield components of Raya Anmol and Faisal Canola under coastal climatic conditions of Lasbela. Am. J. Plant Sci. 5:2230-6.

Wuest SB, Albrecht SL, Skirvin KW, 2000. Crop residue position and interference with wheat seedling development. Soil Till. Res. 55:175-82. 